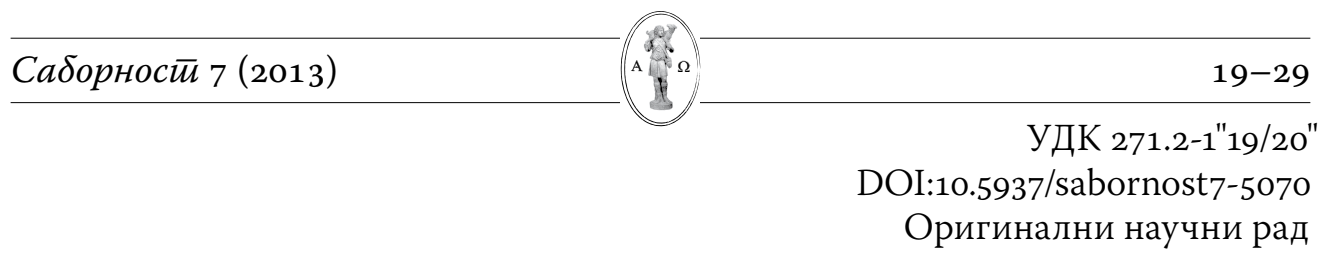

\title{
Радован Биговић
}

Универзитет у Београду, Православни богословски факултет, Београд

\section{Православна теологија у посттеолошкој епохи}

\begin{abstract}
: Црква и православна теологија могу успешно извршавати своју мисију, ако у свако време испитују знакове времена и тумаче их у светлу Еванђеља, ако сваком нараштају могу, на њему разумљив начин, одговорити на вечна људска питања о смислу садашњег и будућег живота. Важно је стога сазнавати и разумевати свет у којем живимо, његова очекивања, тежње и дубоке и брзе промене које се поступно шире целим светом. Богословље као пророчки глас и израз црквеног саморазумевања може функционисати једино као део антиномијског и двоприродног карактера Цркве. Управо као што Црква није од овога света, тако и теологија тежи да изрази благодатно искуство и трансцендентну стварност, која је изнад и иза речи, појмова или имена. Управо као што Црква живи и одлази у свет, тако и теологија тражи дијалог и комуникацију са историјском садашњошћу сваке епохе.
\end{abstract}

Key words: теологија, постмодерна, неопатристичка синтеза, Предање, Црква.

„Но Госйоgа Боїа освећујейе у сриима својим, сваїgа сйремни с кройошћу и сиирахом на оgіовор свако-

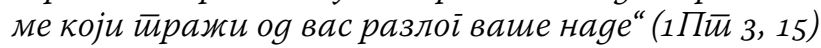

B реме у коме живимо многи називају „посттеолошком епохом“. Неки говоре о „крају теологије“. Други постављају питање: „чему још теологија?“ Трећи говоре да је теологија у „прогонству“, те да се налази пред изазовом опстанка или преживљавања у данашњој култури. Широм света она нестаје из јавног дискурса и то, готово неприметно, из сва три подручја јавног деловања: из Цркве, академске заједнице и друштва. Све се ово дешава упркос мноштву теолога, теолошких школа, публикација и бројних других активности. На први поглед у наше време православна теологија доживљава своју ренесансу. Ова теза може да се поткрепи следећим чињеницама: Православна Црква никада није имала толики број теолошких школа; никада тако квалитетну стручну и популарну теолошку литературу, укључујући и бројне теолошке часописе; теолошки факултети у свим земљама реалсоцијализма налазе се на државним универзитетима; велико интересовање за студије теологије; никад већи 
број магистара и доктора теологије; у традиционално неправославним срединама данас постоје високе православне богословске школе (Париз, Њујорк, Минхен, Бостон, Лондон, Чикаго, Сиднеј итд). Православни теолози, надаље, учествују на разним међуправославним, међухришћанским, интеррелигијским скуповима (конференције, симпосиони, округли столови, семинари). Ту су и учешћа на другим научним скуповима. Православна Црква никада није имала високошколованих епископа, свештеника, монаха, лаика. Многи данас говоре да живимо у раздобљу повратка, ренесансе религиозног и религије, посебно у Источној Европи, где се готово сво становништво изјашњава као религиозно. Међутим, ради се о религији за коју је теологија мртва. И поред свих ових чињеница нема, ипак, места претераном самозадовољству кад је реч о положају теологије данас.

Утицај теологије на свакодневни живот Цркве је мали, готово занемарљив. Многе чињенице показују да је она у Цркви маргинализована. Понекад се осећа и међусобни антагонизам међу њима. Из Цркве можемо чути: теолози су „јалови теоретичари“. Теолози опет упућују критике на рачун свакодневне праксе Цркве. Посебно су незадовољни својим положајем у Цркви. Сматрају да треба да се више питају и консултују код доношења одлука битних за живот Цркве. Стварно стање православне теологије може бити окарактерисано двема речима - збуњеност и бућење. Под збуњеношћу подразумевам очигледан недостатак јединства међу православним теолозима: јединства теолошког језика, јединства метода, сагласности о природи питања и начину њиховог решења. Наша теологија развија мноштво теолошких „кључева“ унутар више међусобно искључивих интелектуалних оквира. Ова конфузија је ипак знак буђења, новог тражења изворне православне перспективе.

„Наша прва дужност у ствари је признање да је теологија вековима била отуђена од Цркве и да је ова отуђеност имала трагичне последице и за теологију и за Цркву. Она (отуђеност) је теологију учинила само интелектуалном активношћу, подељеном на мноштво „дисциплина“ Јез међусобне везе и ठез примене на стварне потребе Цркве. Теологија је престала да буде одговор на питања Цркве, и преставши да буде такав одговор, престала је да буде и питање упућено Цркви. То данас чини од теологије егоцентрични свет у оквиру Цркве, практично изолован од Њеног живота. Теологија живи у себи и за себе мирним академским водама, добро брањена од обичности и радозналости високостручним језиком. Теолози избегавају да расправљају о свакидашњој стварности црквеног живота и не помишљајући да на њега утичу на било који начин“, каже отац Александар Шмеман (Шмеман, 2012).

Често се истиче да теологија мора бити „црквена“, „евхаристијска“, да изражава „црквено искуство“, а у суштини су то радови махом састављени од цитата појединих отаца Цркве и неколико признатих теолошких 
ауторитета, често истргнутих из контекста. Тако је богословље о Цркви својеврсна теолошка философија, а не богословље Цркве. Сви критикују схоластички карактер нововековне православне теологије, њено „вавилонско ропство“, међутим и даље се у великој мери конкретни живот Цркве и теологија налазе на упоредним колосецима, чак у некој врсти притајеног сукоба и нетрпељивости.

На Првој православној теолошкој конференцији, која је одржана у Атини 1936. године, отац Георгије Флоровски, вероватно највећи православни теолог ХХ века и једна од најкрупнијих фигура у међународним екуменским и академским круговима, прогласио је потребу православне теологије да се врати Оцима и да се ослободи „вавилонског ропства“ западној теологији и то на плану језика, полазишних претпоставки и начина мишљења. Тај његов манифест је брзо усвојен од стране већине теолога руске дијаспоре, а потом је имао следбенике у традиционално православним земљама, попут Грчке, Србије, Румуније, Бугарске. Овај теолошки покрет је постао основно обележје православне теологије XX века и за многе је он њен примарни задатак, чак до те мере да су овај славни „повратак Оцима“ и напор да се „од-западњачи“ православна теологија бацили у сенку сва остала теолошка питања, као и изазове које је савремени свет постављао пред православну теологију и која и даље поставља. Крилатица „повратак светим Оцима“ од појединаца није сматрана потпуно прихватљивом, јер се могла протумачити назадном и конзервативном. Као замена је предложена: „напред са светим Оцима“, али ни она није је била опште прихватљива. За многе није правилно изражавала став православне Цркве. Грчки теолог Георгије Мандзаридис сматра да је најправилније рећи: „Следујући светим оцима“ („Ићи за светим оцима“) (Мандзаридис, 2008, стр. 12). Идеја коју је формулисао Флоровски, али „која је лебдела у ваздуху“ током читавог ХХ века, надахнула је многе изванредне истраживаче у области патристике не само међу руском емиграцијом, него и међу западним научницима.

Православна теологија се током последња два века бавила искључиво својим „унутрашњим“ проблемима. „Оправослављење“, бежање од „западних утицаја“ - „вавилонског ропства“, постало је један од њених приоритета. То је имало за последицу њено искључивање из главних савремених токова живота, али и теологије. Неки су идеју „повратка Оцима“ протумачили као редукцију теологије на патристику. То је имало за последицу пренаглашавање патристичких студија, нарушавање равнотеже са другим областима теологије; одбацивање и потцењивање библијских студија; историјски приступ патристичком богословљу; интровертност и готово потпуно одсуство православне теологије из најважнијих богословских дешавања и трендова XX века; и слаб богословски одговор на изазове које поставља савремени свет, уопштено говорећи, нерешена богословска 
питања која још увек постоје у односу између православља и модерности, између православља и модерног света. Треба, међутим, имати на уму да, углавном из историјских разлога, православни свет није органски учествовао у феномену модерности. Он није искусио ренесансу, реформацију или контра-реформацију, верске ратове и просветитељство, Француску и Индустријску револуцију, успон субјекта, људска права и религијски неутралну нацију-државу. Оно што је модерна препознала као свој централни интерес изгледа да је остало страно православљу, које је и даље подозриво према модерности. Ова чињеница засигурно помаже разумевању потешкоћа које православље има у комуникацији са савременим (пост) модерним светом.

Савремени теолошки трендови које је наметао модерни свет, са изузетком можда екуменске теологије, теологије мисије и покрета патристичке и литургичке обнове, не показују да су претрпели било какав утицај од стране православља, премда су значајни православни теолози учествовали, активно, у екуменском покрету од његовога зачећа. Теолошке науке се веома мало баве реалним животом Цркве. Један од разлога за то је свакако и страх теолога од црквених ауторитета. Бојазан да се не замере. Зато су више прибегавали апстрактним теолошким темама.

Протеклих година често је говорено да православна Црква, ако жели да надвлада своје унутрашње слабости и недостатке мора да се врати Оцима. Патристичко оживљавање, неопатристичка синтеза - ови и слични изрази чести су у садашњим радовима православних и несумњиво указују на праву непатворену и хитну потребу. Прекидање живе патристичке традиције било је узрок велике теолошке трагедије православља. Али шта се заиста подразумева под „вратити се“ и како то треба да изведемо? На ова питања није дат ниједан задовољавајући одговор. Да ли то значи само понављање онога што су Оци рекли, под претпоставком да су они рекли све што је битно и да то није ништа друго до рекапитулација њихове сагласности? Таква претпоставка, чак и да стоји, сигурно не би решила проблем који смо поменули раније - садашње теолошко отуђење. Ниједна збирка високостручних патролошких монографија, ниједно издање патролошких текстова за општу употребу не би установили у њима самима живи и креативни одговор на стварна питања нашег времена или на стварне потребе Цркве. Овде би још увек постојала неопходност интерпретације патристичке поруке, њеног „васкрсења“ у мисли Цркве, или другим речима проблем теолошког „пробијања“ (breaking through). Ми, међутим, морамо запамтити да Црква никада није учила да су Оци одговорили на сва питања, да је њихова теологија целовита, и да је данашња теологија само коментатор патристичких текстова. Променити Оце у чисте формалне и непогрешиве ауторитете, што је теологија патристичког схоластицизма и чинила, у ствари је издаја самог духа патристичке теологије, који заувек остаје диван пример духовне слободе и креативности. „Повратак оцима“ изнад свега значи опоравак духа њиховог тајног надахнућа који је од њих направио праве сведоке Цркве (Шмеман, 2012). 


\section{Теологија и академска заједница}

Живимо у друштву у којем се догодио један епохални историјски обрат сцијентизације (побожанствењење, идолатризација науке) целокупне културе, у коме је „научни менталитет“ обележје данашње културе и контекст теолошког промишљања. Стога се може рећи да је данашња култура обележена научношћу као „моделом“ савременога знања, па би се, тобоже, теологија требало ठавити питањима која обликују тај „научни менталитет“. Ово је оставило велике последице и на теологију. Православно богословље углавном примењује методологију друштвених наука, неспособно да изгради властиту методологију.

Теологија је разбијена на мноштво теолошких дисциплина без икаквог садржајног и методолошког обједињавања. Свака наука иде својим сопственим путем. Православна теологија пати од маниризма, архаичког језика, конзервативизма, цитатологије, еклектицизама.

Све до краја Средњег века манастири су били најзначајнији теолошки центри. Теологија се касније из манастира изместила у учионице, кабинете, на Универзитете. Откако је теологија на Универзитету - већина православних Факултета је на државним Универзитетима - она је суочена и организацијски и научно-друштвено с новим изазовима. Као и све друге науке на другим факултетима, она мора стално доказивати не само свој научни значај него и своју друштвену корисност. Реформе које се захтевају од стране политике, која одлучује о додели финансијских средстава, терају је да „укрупни“ своје предмете, те да њихову грађу организује према заданој заједничкој схеми, тако да међународна и међуфакултетска размена студената и професора лакше „тече“; проток знања и научника, за надати се, ठиће на корист напретку теолошких наука. C том надом су и све друге универзитетске организоване научне дисциплине кренуле у реформу, па свака „плива“ у свом „болоњском сосу“ како зна и уме. Премда многоструки подстицаји за теологију долазе и од универзитетске теологије, ипак у целини гледајући, главни замах и обнову даје неуниверзитетска теологија, посебно на Западу. У неким помесним Православним Црквама је ситуација обратна (нпр. Србија). У Србији је Теолошки факултет, од седамдесетих година прошлог века, носилац те обнове у теологији и уопште православног Предања у животу Цркве. Но, потребно је споменути да је један од разлога таквога стања и сам универзитетски амбијент. Наведимо само неке елементе: уходаност предавања лако претвара теологију у мануалистичко-уџбеничку, која се из године у годину понавља без потреठе за даљим продубљивањима; бирократичност факултета која све више сужава простор за слободно време истраживања; одређени научни идеал универзитетске теологије који не допушта било какво промишљање изван тога идеала, па се све ново у теологији проглашава ненаучним, а тиме и неприхватљивим. 


\section{Друштвена релевантност теологије}

Последњих година православна теологија показује повећан интерес за екуменску теологију, питање биоетике, теологију религија, социјална питања. На факултетима се и формирају посебне катедре за те области. Но, друштво не показује скоро никакв интерес за теологију. Постоје отпори присуству теолошких факултета на Универзитету. Многи су још на позицијама „конфликта“. Још су актуелне тезе о „ненаучности теологије“. Теолошке науке се све више замењују религиолошким наукама. Теологија се у неким европским земљама развија све више у правцу религијских студија, ठез конфесионалнога одређења. За те науке постоји велики интерес. Европска унија не жели да финансира теолошке пројекте, али религиолошке врло радо.

Православна теологија треба да се активно укључи у социолошку, политичку и психолошку анализу и критику друштва, тим пре што је политика постала савремена религија, политичко идолопоклонство. Теологија се увек ठави егзистенцијалним проблемима човека, али треба да говори језиком постмодерне. Она треба да делује двосмерно: ad intra и ad extra. Предмет теологије је Бог-свет-човек и њихов међусобни однос, тј. целокупна стварност. Православна Црква је есхатололошка. Повратак оцима, или следовање Оцима, је „сећање на будућност“, а не повратак „старини“ и враћање у прошлост. Свет науке и технологије треба Црква да надахне Јеванђељем, да освети целокупну творевину, постмодерну. „Немогуће је данас имати истинско Откровење Бога а да се као материјал за то Откровење не искористе данашње друштвене, културолошке, научне и друге чињенице. Бог не може човека покренути на други начин, осим путем контакта са његовим конкретним, историјским телом. Он не може спасити човека на други начин, осим да преобрази његов живот“, каже грчки теолог Панајотис Нелас (Нелас, 2012). Теологија не може да буде актуелна копирањем, подражавањем, имитирањем, секуларизацијом. Мора да ठуде аутентична.

\section{Реафирмација православног богословља}

Црква и православна теологија могу успешно извршавати своје мисију, ако у свако време испитују знакове времена и тумаче их у светлу Еванђеља, ако сваком нараштају могу, на њему разумљив начин, одговорити на вечна људска питања о смислу садашњег и будућег живота. Важно је стога сазнавати и разумевати свет у којем живимо, његова очекивања, тежње и дубоке и брзе промене које се поступно шире целим светом.

Савремена православна теологија треба да направи једну чврсту синтезу и равнотежу између своје црквене и академске димензије. Црква и њено богословље не могу да дозволе да академско (болоњско) разори црквено. 
Позитиван став према научним достигнућима не искључује црквени карактер теологије и обратно.

Велики непријатељ и извитоперење православног богословља представља његов конфесионални карактер, који је „увезен“. Данас је неопходна његова деконфесионализација. Наша теологија мора да узме у обзир достигнућа католичке и протестантске мисли. Теологија мора да има важност за све, за цео свет, или нема никакво значење. Двадесети век је дао много у области изучавања светоотачког наслеђа, како захваљујући новим критичким издањима дела Светих отаца, тако и захваљујући делима научника Истока и Запада. Али, да ли смо успели да достигнемо ту „неопатристичку синтезу“ о којој су сањали ови истраживачи? Мислим да нисмо.

Да би се у томе успело, неопходно је: институционално повезивање православних теолошких факултета и школа, размена професора и студената, стварање заједничких часописа и других публикација, и њихова размена, стварање неке богословске дисциплине која би обједињавала најбоља теолошка достигнућа, често организовање заједничких семинара, округлих столова, конференција, симпосиона. Свакако се подразумева континуирани дијалог црквених школа са парохијама, епархијама, манастирима и другим духовним центрима.

Важно је и битно непрестано изграђивање и конституисање изворног православног богословског ума, метода и језика. Постмодерна и посттеолошка епоха све више користи енглески језик као универзални језик. Ако хоће да има неко шире значење, православна теологија ће морати све више да говори тим језиком, али мора да води рачуна о очувању локалних језика и култура. Православне теологије данас имају претежно локални карактер (теологија је мање-више затворена у границе националних Цркава). Веома слабо се познају теологије других помесних Цркава. Међу њима не само што не постоји размена ни међузависност, већ постоји међусобно непознавање, игнорисање, па и нетрпељивост.

Треба да пронађемо нови приступ Библији и Оцима који би дозволио да се још потпуније сагледа библијско и светоотачко наслеђе. Дубоко сам уверен да један од основних и најпотребнијих елемената у новом присту-

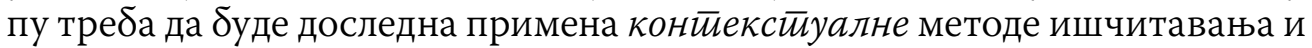
тумачења тих дела у контексту Светог Предања, којим Црква живи и дише. На овоме данас посебно инсистира угледни руски митрополит, теолог и уметник Иларион Алфејев.

Богословље као пророчки глас и израз црквеног саморазумевања може функционисати једино као део антиномијског и двоприродног карактера Цркве. Будући да Црква није од овога света, теологија тежи да изрази благодатно искуство и трансцендентну стварност, која је изнад и иза речи, појмова или имена. Управо као што Црква живи и одлази у свет, тако и теологија тражи дијалог и комуникацију са историјском садашњошћу 
сваке епохе, усвајајући језик, тело и мисаони свет сваке поједине епохе историјске и културне садашњице датога времена. Теологија се не протеже паралелно са историјом и не може се поистоветити са историјом, али исто тако не може функционисати мимо историје. Што је још важније, она не може наставити да игнорише лекције историје. Без овог процеса непомешане размене и рецепције света и историје - без овог чина дијалога, кретања ка свету и „сведочења“ њему - ни Црква, ни теологија не могу постојати, утолико што и Црква не постоји сама за себе већ за свет и за добробит света: „за живот света“. На крају крајева, Божје Откровење се увек одигравало унутар твари и историје, а не у неком не-историјском, безвременом универзуму који није повезан са светом. Као што је пре двадесет и пет година пророчки рекао покојни грчки теолог Панајотис Нелас, оснивач познатог теолошког часописа Synaxis: „... немогуће је данас имати истинско Откровење Бога, а да се као материјал за то Откровење не искористе данашње друштвене, културолошке, научне и друге чињенице. Бог не може човека покренути на други начин осим путем контакта са његовим конкретним, историјским телом; Он не може спасити човека на други начин осим да преобрази његов живот." (Нелас, 2012) Размишљајући даље у овом правцу, могли бисмо још рећи да је бестелесна теологија, теологија која одбија разговор са ширим друштвеним и културним стварностима свога времена, непојмљива, без обзира на то да ли је у питању њен однос са модерном, постмодерном или касном модерном. Теологија која на себе не узима „тело“ свога времена једнако је непојмљива као што је непојмљиво да Црква може бити изолована, да може одбити да изађе из себе и да се сусретне са светом и историјом, да га јеванђелизира и да га преобрази. Тако, Црква и њено богословље не могу ићи напред у свету док истовремено игноришу или потцењују свет који их окружује, само зато што свет не може бити „хришћански“, или због тога што он није такав каквим би га они желели. Слично томе, Црква и њено богословље не могу мотивисати људе данашњице, људе модерне и касне модерне, докле год Црква ниподаштава и потцењује савремени свет и докле год заборавља да је он материјал откровења и тело које треба преузети на себе.

Према томе, оно што је неопходно није понављање и наставак порицања и резервисаности, што често карактерише православне у њиховом односу према модерности, већ један креативни сусрет и један низ теолошких дијалога са свим изазовима које модерност поставља. Хоће ли православна Црква, верна обновљеном теантропизму и аутентичној теологији Оваплоћења и надахнута визијом и искуством Васкрсења, примити у себе предање, смелост и ум Отаца и грандиозну богословску синтезу коју су они израдили, углавном на Истоку? Хоће ли она ући у дијалог и чак покушати (зашто не?) остваривање једне нове синтезе са оним што је најбоље у модерном свету, користећи се сусретом Истока и Запада? 
Теологија је позвана да отвара нове путеве приступа Богу! Средином прошлог века догодио се прекид с традицијом веома великих размера. Код не малог броја је делотворна неодређена жеља за живим Богом, а многи траже нови облик хришћанског живота. Ако постмодерна религиозност нуди нове облике духовности, није ли тим више управо теологија позвана да се заузме на подручју духовности, увек свесна да се на крају Богу не приступа спољашњим поступком - објашњавањем, доказивањем и закључком, него унутрашњим поступком - искуством и проверавањем тога искуства? Бог није предмет знања, већ субјекат теологије и сваког познања. Дакле, теологија у доба постмодерне не би требало само да пита „шта је било?“, него такође (ако не на првом месту) „шта има ново?“ (Bigović, 2009). Теологија се не сме „бавити собом“, јер јој тада прети опасност да остане стерилна. Док постмодерна без критеријума прихвата све, теологија се треба ослонити и на разум, али би коначно требало и прегрмети страх од парадокса. Теологија треба да отвори врата за поглед изнутра, из Предања и искуства Цркве. Коначно, проблем теологије у доба постмодерне су понајпре теолози, који уместо да буду пророци, остадоше занатлије! Теолог будућности не сме се задовољити тиме да остане „чувар напуштених путева", него мора крчити нове стазе које воде од човека Богу и од Бога човеку.

\section{Есхатолошка димензија теологије}

Православни кроз векове сведоче да православна еклисиологија има есхатолошки карактер. То нас упућује на закључак о есхатолошком карактеру православне теологије, који још није довољно истражен и артикулисан. Та димензија толико недостаје у наше време, тако да и не примећујемо погрешне одговоре на изазов глобализације и космополитизма, у виду ветрова традиционализма и фундаментализма, који поново силовито дувају кроз живот и богословље Цркве. Есхатологија јесте активно и веома захтевно очекивање доласка Царства Божјег, новога света који очекујемо. Као таква, она се улива у динамичну посвећеност садашњости, афирмацију и отвореност ка будућности Царства у којој се налази пуноћа и идентитет Цркве. Другим речима, Црква своју суштину у основи не задобија из онога што она јесте, већ из онога што ће она постати у будућности, у есхатолошком времену које је, од Васкрсења Христовога и силаска Светога Духа на дан Педесетнице, већ почело да нас обасјава и да утиче на садашњост и на историју. У светлости есхатологије, и само Предање Цркве задобија ново значење и другачију димензију оптимистичку и перспективу пуну наде. У овој перспективи, Предање се не поистовећује са навикама, обичајима, предањима или идејама или, уопштено говорећи, са историјском инертношћу и стагнацијом, већ са личношћу, Исусом Христом, Господом славе који долази. Као што нас 
свети Кипријан Картагински подсећа: „Господ је казао: Ја сам истина. Он није рекао: Ја сам обичај“. Предање се, дакле, не односи у првом реду на прошлост, оно није везано за обрасце прошлости, за догађаје који су се већ одиграли. Ма како то чудно звучало, у аутентичној еклисиолошкој перспективи, Предање је оријентисано ка будућности. Оно начелно и превасходно долази из будућег Царства Божјег, од Онога који долази, од онога што тек треба да буде откривено у пуноћи и објављено, од Божје љубави и плана који је Он припремио за нас, за спасење света и човека. Тако се есхатолошко поимање Предања показује као саобразно павловској дефиницији вере: „А вера је основ свега чему се надамо, потврда ствари невидљивих“ (Јев 11, 1. уп. Јев 1; Рим 8, 24), или као аналогно есхатолошком или „будућем“ сећању какво окушамо у молитви Анафоре на Светој литургији Светог Јована Златоустог: „Сећајући се дакле ове спасоносне заповести, и свега што се нас ради збило: Крста, Гроба, тридневнога Васкрсења, Узласка на небеса, Седења с десне стране, $u$ Друїоі и славноі gоласка“. Разлог томе је тај што према коментарима Ареопагитских списа који се приписују Светом Максиму Исповеднику (но које данашња наука сматра делом Јована Скитопољског), читава Божанска Литургија представља не неке вечне небеске архетипове или неку стварност у свету идеја, већ есхатолошко Царство које ће доћи, стварност будућности у којој је смештена истина ствари и симбола. Зато, управо као што последње ствари дају биће првима, и есхатологија протологији, тако је и Царство Божје - пуноћа живота и истине која ће се испунити и која ће у потпуности ठити откривена у есхатону - то које одређује и даје смисао Предању Цркве. Будућност је дакле узрок, а не последица прошлости, Гледано из овога угла, дакле, Предање није слово које убија, носталгично понављање или некритичко прихватање или настављање прошлости, већ креативни континуитет у Светоме Духу и отвореност ка будућности, ка новоме свету Царства Божјег које чекамо.

\section{Литература:}

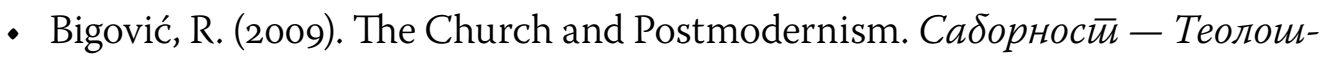
ки іолишњак, III, 177-183.

- Мандзаридис, Г. (2008). Православни gуховни живой. Манастир Хиландар.

- Нелас, П. (2012). Евхарисииија као охрисйовљење и ирреображење. Преузето 21. 2. 2012. ca http://www.spc-mladenovac.org.yu/Tekstovi/Panajotis_ Nelas-Evharistija_kao_ohristovljenje_i_probrazenje. pdf

- Шмеман, А. (2012). Теолоїија и евхарисииија. Преузето 21. 2. 2012. са http://www.verujem.org/teologija/schmemann. html 


\title{
Radovan Bigović
}

University of Belgrade, Faculty of Orthodox Theology, Belgrade

\section{The Orthodox Theology In the Post-theological Era}

\begin{abstract}
Church and Orthodox theology can successfully carry out their missions, considering they examine the signs of the times and interpreting them in the light of the Gospel at any time, if they can offer every generation, in their understandable way, an answer to the eternal human questions about the meaning of the present and future life. It is, therefore, important to learn and understand the world in which we live, its expectations, aspirations and profound and rapid changes that are gradually spreading all over the world. Theology as a prophetic voice and expression of the Church's self-understanding can only function as a part of antinomy and two-naturalness of the Church's character. Just as the Church is not of this world, so tends theology to express the experience of grace and transcendent reality which is above and beyond words, terms or names. As the Church lives and goes into the world, so does theology seek a dialogue and communication with the historical present in every age.
\end{abstract}

Key words: Theology, Postmodernism, Neo-patristic Synthesis, Tradition, Church.

Датум пријема чланка: 20. 2. 2012.

Датум прихватања чланка за објављивање: 31. 5. 2013. 